\title{
THE EFFECTS OF SOME ANTI-OESTROGENS ON THE DECIDUOMA REACTION AND DELAYED IMPLANTATION IN THE MOUSE
}

\author{
K. W. HUMPHREY \\ Department of Veterinary Physiology, University of Sydney, \\ Sydney, New South Wales, Australia
}

(Received 20th Fune 1967, revised 9th December 1967)

\begin{abstract}
Summary. Zygotes recovered from the oviducts and uteri of mice treated with the anti-oestrogens DMs, MRL 37 or MER 25 implanted normally after transfer to pseudopregnant host mice, but treatment of the hosts with an anti-oestrogen inhibited implantation. Induction of deciduomata in intact and ovariectomized mice was prevented by prior treatment with oestradiol or one of the anti-oestrogens, although MER 25 and MRL 37 were less effective in ovariectomized mice. When implantation was delayed by ovariectomy, MRL 37 and MER 25 largely prevented oestradiol-induced implantation on Day 8 without affecting the recovery of blastocysts, but DMs induced implantation in some mice and did not significantly affect the induction of implantation by oestradiol. DMS, and to a lesser extent MRL 37, caused oestrogenic changes in the endometrium on Day 4. It is concluded that the antifertility actions of DMS are due to oestrogenicity, but those of MER 25 and MRL 37 may be due to their anti-oestrogenic properties.
\end{abstract}

\section{INTRODUCTION}

Although the antifertility properties of various anti-oestrogenic compounds have been well documented, their mode of action is not always clear (Martin, Emmens \& Cox, 1960; Emmens \& Martin, 1964; Emmens, 1965a, b; Jackson, 1966). Norethynodrel and the anti-oestrogens, clomiphene (MRL 41) and MER 25 were believed to be blastotoxic (Segal \& Nelson, 1958; Davis, 1963a; Schlough \& Meyer, 1965a) but ovum transfer studies have shown that norethynodrel and MRL 41 do not affect the zygotes but prevent implantation by an effect on the endometrium (Davis, 1963b; Staples, 1966, respectively).

Humphrey \& Martin (1968, unpublished data) showed that the anti-oestrogens, dimethyl-stilboestrol (DMs), 1-( $p$-2-diethylaminoethoxyphenyl)-1-phenyl2-anisylethanol (MER 25) and 1-( $p$-2-diethylaminoethoxyphenyl)-1-phenylanisylethane (MRL 37) had a similar action to oestradiol in causing tube-locking of zygotes, which were morphologically normal. However, Chang (1959) has pointed out that MER 25 may prevent implantation by causing damage to the zygote at a biochemical level.

The following experiments were performed to differentiate between the 201 
maternal and zygotic effects of DMs, MRL 37 and MER 25 in mice by ovum transfer studies, by the induction of deciduomata and by delaying implantation by ovariectomy.

\section{MATERIALS AND METHODS}

Randomly bred virgin mice of the QS strain, aged 10 to 16 weeks, were kept under constant conditions as described by Humphrey \& Martin (1968). Pregnant and pseudopregnant females were obtained by mating with fertile and vasectomized males, respectively - the day of finding the vaginal plug was termed Day 1 of pregnancy or pseudopregnancy. The schedule of experiments was as follows:

\section{Ovum transfer experiments}

On Days 1, 2 and 3 of pregnancy, donor mice received injections of the test substances at doses known to cause maximal disturbance of tubal transport (Humphrey \& Martin, 1968, unpublished data). These mice were killed bycervical dislocation on Day 4, and the zygotes recovered for transfer to pseudopregnant host mice. The zygotes were flushed from the oviducts of mice treated with DMS and MRL 37 (treated ova), and from the uteri of mice treated with the vehicles, peanut oil or dimethylsulphoxide (control ova). MER 25 causes only partial tube-locking and zygotes were recovered from both the oviducts and uterine horns. After recovery, the ova were stored in Krebs' Ringer phosphate buffer ( $\mathrm{pH} 7.4$ ) containing $0.1 \%$ of glucose and $0.1 \%$ of bovine serum albumin until transfer to host mice. Uteri of these donor mice and of a further ten mice given $400.0 \mu \mathrm{g} /$ day of DMS and killed on Day 4 were fixed in Bouin's solution and $7 \mu$ histological sections were stained with haematoxylin and eosin.

Host mice received the same dosage of the corresponding vehicle of substance on Days 1 to 3 of pseudopregnancy and ovum transfers were made on the afternoon of Day 4. Under Avertin anaesthesia $(0.1 \mathrm{ml}$ of a $2.5 \%$ solution $/ 10 \mathrm{~g}$ body weight), the two uterine horns were exteriorized through dorsal wall incisions. Five zygotes from control mice were placed in one horn, and five zygotes from treated mice placed in the other horn, at random. The hosts were killed on Day 14 and both horns examined for implants. The distribution of implants was analysed, isolating the mean squares for differences between hosts, between ova and between horns. The possibility of 'cross-over' of zygotes between horns was ignored as this was found to occur only rarely (see also Runner, 1951; McLaren \& Michie; 1956, Davis, 1963b).

\section{Induction of deciduomata}

The effects of the compounds on the deciduoma reaction were studied in pseudopregnant and in progesterone-treated ovariectomized mice. Deciduomata were induced in pseudopregnant mice by intraluminal injection of $10 \mu \mathrm{l}$ of peanut oil at 18.00 hours on Day 4. Ovariectomized mice were primed with $0.1 \mu \mathrm{g}$ of oestradiol for 3 days followed by $0.8 \mathrm{mg} /$ day of progesterone. Deciduomata were induced at noon on Day 5 of progesterone treatment by intrauterine injection of the histamine releaser, Compound $48 / 80(100 \mu \mathrm{g}$ in $10 \mu \mathrm{l}$ of 
saline). The test substances were given on the 3 days before deciduoma induction, i.e. on Days 1 to 3 of pseudopregnancy and Days 2 to 4 of progesterone treatment. The mice were killed $96 \mathrm{hr}$ after induction and the deciduomata weighed and scored by the deciduoma induction score (DIS) of 0 to 4 as used by Shelesnyak \& Kraicer (1961). This score is based on the length of the injected horn containing deciduomata so that a DIs of 4 is for a full-length reaction, and a DIS of 1 is for an isolated reaction. The deciduoma weight was taken as the weight difference between treated (right) and non-treated (left) horns.

\section{Experiments on delayed implantation}

Pregnant mice were ovariectomized at 08.00 hours on Day 4 , and received $1.6 \mathrm{mg} /$ day of progesterone on Days 4 to 8 . This treatment delays implantation in most mice until oestradiol is given (Humphrey, 1967a) -the occurrence of the implants found in some mice not given oestradiol (termed 'spontaneous' implants) is presumably because ovariectomy was too late to block the action of endogenous oestrogens. A total of sixteen mice/group received daily injections of an anti-oestrogen or vehicle on Days 5 to 7 . Eight mice/group were killed on Day 8 and the uteri examined for implants or free blastocysts, to see if the antioestrogens could induce implantation of those delayed and to determine the incidence of 'spontaneous' implants in the vehicle-treated animals. The remaining eight mice/group received $0.024 \mu \mathrm{g}$ of oestradiol on Day 8 to induce implantation, and the implants were maintained by daily injections of $1.6 \mathrm{mg}$ of progesterone and 0.008 $\mu \mathrm{g}$ of oestradiol on Days 9 to 11 (Humphrey, 1967b). The mice were killed on Day 12 and examined for implants or blastocysts to investigate the effects of the anti-oestrogens on oestradiol-induced implantation. On Day 12 implants induced by oestradiol on Day 8 ('induced' implants) had developed for 4 days only and were obviously smaller than those which had begun development before the injection of oestradiol ('spontaneous' implants), in which defined embryos had formed.

The substances under test were dissolved in peantit oil or dimethylsulphoxide and given by subcutaneous injections in $0.1 \mathrm{ml}$ of vehicle. Analyses of variance of all data were performed but, to conserve space, are not included. The number of mice with implants was analysed by $\chi^{2}$ (corrected) in a $2 \times 2$ table. Levels of statistical significance are mentioned in the text.

\section{RESULTS}

\section{Ovum transfer experiments}

The results, summarized in Table 1 , show that there was no difference in implantation rate between ova obtained from control or treated donors. However, treatment of the host before transfer markedly reduced or abolished implantation of the transferred ova $(P<0.001$ for all anti-oestrogens).

Examination of histological sections showed that all sixteen mice treated with $40.0 \mu \mathrm{g}$ or $400.0 \mu \mathrm{g} /$ day of DMs on Days 1 to 3 and killed on Day 4 showed typical oestrogenic stimulation of the endometrium; the secretory cells of the stromal glands were taller and the glands were enlarged and contained secretion. The cells of the luminal epithelium and of the stroma were unchanged. This 
secretory endometrium was similar to that produced by oestradiol, 0.1 or 0.4 $\mu \mathrm{g} /$ day, but not as pronounced as that formed after $1.6 \mu \mathrm{g} /$ day. Five of eight mice and two of six mice given 1.0 mg/day of MRL 37 or $4.0 \mathrm{mg} /$ day of MER 25, respectively, exhibited similar hypertrophy and secretion of the stromal glands.

\section{TABLE 1}

THE EFFECTS OF OESTRADIOL AND SOME ANTI-OESTROGENS ON IMPLANTATION IN OVUM TRANSFER EXPERIMENTS

\begin{tabular}{|c|c|c|c|c|c|}
\hline \multirow{2}{*}{$\begin{array}{l}\text { Treatment of host } \\
\text { mice on Days } 1 \text { to } 3\end{array}$} & \multirow{2}{*}{$\begin{array}{c}\text { Daily } \\
\text { dose }\end{array}$} & \multirow{2}{*}{$\begin{array}{l}\text { No. } \\
\text { of } \\
\text { mice }\end{array}$} & \multirow{2}{*}{$\begin{array}{l}\text { No. with } \\
\text { implants } \\
\text { on Day } 14\end{array}$} & \multicolumn{2}{|c|}{ Mean no. of implants } \\
\hline & & & & $\begin{array}{l}\text { Horn with } \\
\text { 'control' ova }\end{array}$ & $\begin{array}{l}\text { Horn with } \\
\text { 'treated' ova }\end{array}$ \\
\hline $\begin{array}{l}\text { Peanut oil } \\
\text { DMS }\end{array}$ & $\begin{array}{r}0.1 \mathrm{ml} \\
400.0 \mu \mathrm{g}\end{array}$ & $\begin{array}{l}6 \\
6\end{array}$ & $\begin{array}{l}6 \\
0\end{array}$ & $\begin{array}{l}3.5 \\
0.0\end{array}$ & $\begin{array}{l}2 \cdot 3 \\
0.0\end{array}$ \\
\hline $\begin{array}{l}\text { Dimethylsulphoxide } \\
\text { MRL } 37\end{array}$ & $\begin{array}{l}0.1 \mathrm{ml} \\
1.0 \mathrm{mg}\end{array}$ & $\begin{array}{l}10 \\
10\end{array}$ & $\begin{array}{l}8 \\
3\end{array}$ & $\begin{array}{l}2 \cdot 3 \\
0 \cdot 3\end{array}$ & $\begin{array}{l}1 \cdot 8 \\
0 \cdot 3\end{array}$ \\
\hline $\begin{array}{l}\text { Dimethylsulphoxide } \\
\text { MER } 25 \text { (uterine ova) }\end{array}$ & $\begin{array}{l}0.1 \mathrm{ml} \\
4.0 \mathrm{mg}\end{array}$ & $\begin{array}{l}12 \\
12\end{array}$ & $\begin{array}{r}10 \\
1\end{array}$ & $\begin{array}{l}2 \cdot 3 \\
0 \cdot 1\end{array}$ & $\begin{array}{l}2 \cdot 6 \\
0.0\end{array}$ \\
\hline $\begin{array}{l}\text { Dimethylsulphoxide } \\
\text { MER } 25 \text { (tubal ova) }\end{array}$ & $\begin{array}{l}0.1 \mathrm{ml} \\
4.0 \mathrm{mg}\end{array}$ & $\begin{array}{l}6 \\
6\end{array}$ & $\begin{array}{l}5 \\
1\end{array}$ & $\begin{array}{l}3 \cdot 0 \\
0.0\end{array}$ & $\begin{array}{l}2 \cdot 7 \\
0 \cdot 3\end{array}$ \\
\hline
\end{tabular}

Each mouse received five ova from control mice to one uterine horn and five ova from donor mice given the corresponding treatment on Days 1 to 3 of pregnancy to the other horn.

\section{Effects on the deciduoma reaction}

Eighteen of twenty-two pseudopregnant mice treated with the vehicles, peanut oil or dimethylsulphoxide, on Days 1 to 3 developed very large deciduomata after local oil injections on Day 4 (Table 2), but no mouse given oestradiol

\section{TABLE 2}

THE EFFECT OF OESTRADIOL AND SOME ANTI-OESTROGENS ON THE DEGIDUOMA REAGTION IN PSEUDOPREGNANT MICE

\begin{tabular}{l|c|c|c|c}
\hline \multicolumn{1}{c|}{$\begin{array}{c}\text { Treatment on Days } \\
1 \text { to } 3\end{array}$} & $\begin{array}{c}\text { Daily } \\
\text { dose }\end{array}$ & $\begin{array}{c}\text { No. with } \\
\text { deciduomata }\end{array}$ & $\begin{array}{c}\text { Mean } \\
\text { DIS }\end{array}$ & $\begin{array}{c}\text { Mean uterine } \\
\text { wt difference }(m g)\end{array}$ \\
\hline Peanut oil & $0.1 \mathrm{ml}$ & 9 & 3.0 & 419.0 \\
Oestradiol & $0.4 \mu \mathrm{g}$ & 0 & 0.0 & 3.0 \\
DMs & $400.0 \mu \mathrm{g}$ & 0 & 0.0 & 6.0 \\
Dimethylsulphoxide & $0.1 \mathrm{ml}$ & 9 & 3.3 & 483.0 \\
MRL 37 & $1.0 \mathrm{mg}$ & 0 & 0.0 & 6.0 \\
MER 25 & $4.0 \mathrm{mg}$ & 0 & 0.0 & 8.0 \\
\hline
\end{tabular}

Deciduomata were induced on Day 4 of pseudopregnancy by local injections of $10 \mu l$ of peanut oil. All results are expressed as means for eleven mice/group killed on Day 8.

or an anti-oestrogen developed deciduomata (treatments versus control, $P<0.001$ for deciduoma scores and weights). In the ovariectomized mice (Table $3)$ the same doses of oestradiol or DMS again completely inhibited decidualization $(P<0.001)$, but MER 25 and MRL 37 were less effective than in intact mice. The data for the latter treatments, summarized from two experiments, show 
that a daily dose of $8.0 \mathrm{mg}$ of MER 25 is needed to inhibit completely the formation of deciduomata, and two of six mice given the highest dose of $2.0 \mathrm{mg} /$ day of MRL 37 had small deciduomata at the site of injection of Compound 48/80.

TABLE 3

THE EFFECTS OF OESTRADIOL AND SOME ANTI-OESTROGENS ON THE DEGIDUOMA REACTION IN OVARIECTOMIZED MICE

\begin{tabular}{|c|c|c|c|c|c|}
\hline $\begin{array}{l}\text { Treatment on Days } \\
2 \text { to } 4 \text { of progesterone }\end{array}$ & $\begin{array}{l}\text { Daily } \\
\text { dose }\end{array}$ & $\begin{array}{l}\text { No. of } \\
\text { mice }\end{array}$ & $\begin{array}{l}\text { No. with } \\
\text { deciduomata }\end{array}$ & $\begin{array}{l}\text { Mean } \\
\text { DIS }\end{array}$ & $\begin{array}{c}\text { Mean uterine wt } \\
\text { difference }(\mathrm{mg})\end{array}$ \\
\hline Peanut oil & $0.1 \mathrm{ml}$ & 5 & 5 & $4 \cdot 0$ & $230 \cdot 0$ \\
\hline Oestradiol & $0.4 \mu \mathrm{g}$ & 5 & 0 & $0 \cdot 0$ & $4 \cdot 0$ \\
\hline DMS & $400 \cdot 0 \mu \mathrm{g}$ & 5 & 0 & 0.0 & $3 \cdot 0$ \\
\hline Dimethylsulphoxide & $0.1 \mathrm{ml}$ & 11 & 11 & $2 \cdot 8$ & $117 \cdot 0$ \\
\hline MRL 37 & $\begin{array}{l}0.5 \mathrm{mg} \\
1.0 \mathrm{mg} \\
2.0 \mathrm{mg}\end{array}$ & $\begin{array}{r}6 \\
11 \\
6\end{array}$ & $\begin{array}{l}4 \\
3 \\
2\end{array}$ & $\begin{array}{l}1.7 \\
0 \cdot 3 \\
0 \cdot 3\end{array}$ & $\begin{array}{l}66 \cdot 0 \\
17 \cdot 0 \\
10 \cdot 0\end{array}$ \\
\hline MER 25 & $\begin{array}{l}2.0 \mathrm{mg} \\
4.0 \mathrm{mg} \\
8.0 \mathrm{mg}\end{array}$ & $\begin{array}{r}6 \\
11 \\
6\end{array}$ & $\begin{array}{l}6 \\
8 \\
0\end{array}$ & $\begin{array}{l}1.7 \\
1.5 \\
0.0\end{array}$ & $\begin{array}{r}49 \cdot 0 \\
44 \cdot 0 \\
5.0\end{array}$ \\
\hline
\end{tabular}

Deciduomata were induced on Day 5 of progesterone treatment by local injection of $100 \mu \mathrm{g}$ of Compound 48/80, and the mice killed on Day 9.

These findings are surprising since the induction of deciduomata in pseudopregnant mice and implantation in mated mice is completely prevented by 1.0 $\mathrm{mg} /$ day of MRL 37 or $4.0 \mathrm{mg} /$ day of MER 25 (Table 2 and Humphrey \& Martin, unpublished data). The deciduomata in the anti-oestrogen treated mice were slightly smaller than in control animals.

\section{Effects on delayed implantation}

The results in Table 4 show that only one of thirty-two vehicle-treated mice killed on Day 8 or 12 had spontaneous implants, while treatment with oestradiol on Day 8 induced implantation in nine of sixteen mice and only one mouse still had free blastocysts on Day 12. Treatment with MRL 37 and MER 25 almost completely prevented oestradiol-induced implantation $\left(\chi^{2}{ }_{1}=7 \cdot 1, P<0.01\right)$ although most mice had free blastocysts on Day 12. These treatments apparently do not themselves induce implantation since spontaneous implants were found in only one of sixteen mice per group given MRL 37 or MER 25.

Quite different results were obtained with DMS. Spontaneous implants were found in two and three of sixteen mice given either 40 or $400 \mu \mathrm{g} /$ day of DMS, respectively, as compared to one of thirty-two mice given dimethylsulphoxide or peanut oil. These data suggest that DMs may itself induce implantation of delayed blastocysts, but this effect is not significant (vehicle $\times \mathrm{DMs} \chi^{2}{ }_{1}=1 \cdot 7, P>0 \cdot 1$ ). One mouse given $400.0 \mu \mathrm{g}$ of DMS and oestradiol on Day 8 and killed on Day 12 had three small implants (arbitrarily termed induced implants) and seven large implants with formed embryos which had obviously developed for close to 8 days (termed spontaneous implants). This may be a case of incomplete implantation as described by Zeilmaker (1963) or merely failure of some implants to develop. 


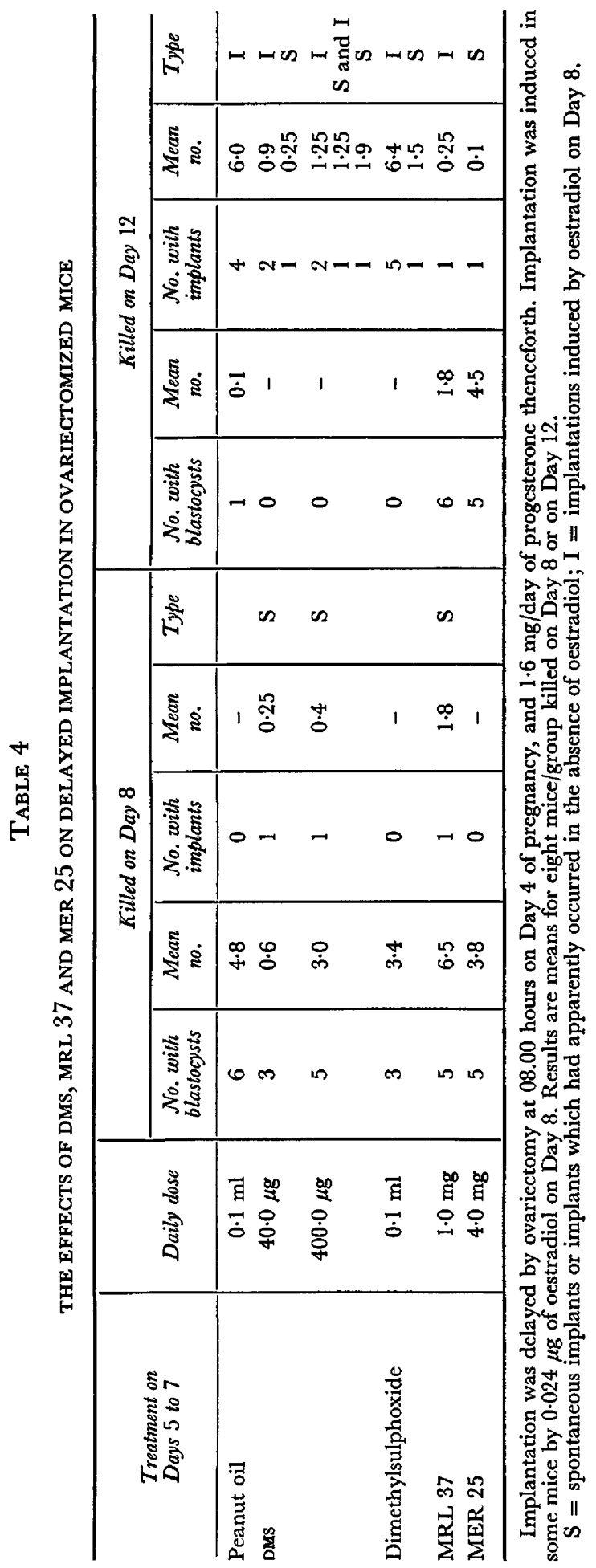


DMS does not significantly affect the induction of implantation by oestradiol on Day 8. Two of eight mice given each dose of DMS and killed on Day 12 had small implants presumably induced by oestradiol on Day 8 (DMs versus control $\left.\chi_{1}^{2}=1 \cdot 8, P>0 \cdot 1\right)$.

\section{DISCUSSION}

The ovum transfer experiments have shown conclusively that the anti-oestrogens are not zygotoxic but prevent implantation by an effect on the maternal environment. These findings are of particular importance in the case of MER 25 which has been thought to be specifically zygotoxic (Segal \& Tyler, 1958; Chang, 1959). However, Biggers (1963) has stated that this action is evident only at high, non-physiological levels.

Oestradiol and the anti-oestrogens have anti-decidual actions and inhibit the deciduoma reaction in intact and hormone-treated, ovariectomized mice (see also Stone \& Emmens, 1964a, b; Schlough \& Meyer, 1965b). Uterine sensitivity or the capacity of the uterus to decidualize (Long \& Evans, 1922) depends on a delicate balance in the absolute and relative levels of progesterone and oestrogen, although these requirements vary with the nature of the inducing stimulus (Courrier, 1950; Finn, 1965, 1966; Humphrey, 1967b). Assuming adequate progesterone, decidualization can be prevented by either a deficiency or an excess of oestrogen or by antagonism of the actions of oestrogen by an anti-oestrogenic compound (Courrier, 1950; Martin et al., 1960).

Implantation and the induction of deciduomata by intraluminal oil in intact or ovariectomized mice are strictly oestrogen dependent (Finn, 1965, 1966: Humphrey, 1967a, b) although the blastocyst appears to be somewhat resistant to the actions of oestrogens (see Brouha, 1934; Courrier, 1950; Finn \& Emmens, 1961; Stone \& Emmens, 1964a). Thus, a single dose of $0.025 \mu \mathrm{g}$ of oestradiol increases uterine sensitivity to local oil and permits the induction of deciduomata in ovariectomized mice, but a dose of $0.1 \mu \mathrm{g}$ inhibits decidualization (Humphrey, 1967b and unpublished observations; see Finn, 1966). In contrast, doses of $0 \cdot 00125,0 \cdot 025$ or $2.5 \mu \mathrm{g}$ are equally effective in inducing implantation of delayed zygotes and inhibition does not occur with the highest dose (Humphrey, 1967a). Oestrogen is not essential for the induction of deciduomata in progesterone-treated, ovariectomized mice by traumatic stimuli such as crushing or Compound $48 / 80$ but this induction is readily inhibited by an excess of oestrogen (Courrier, 1950; Finn, 1966; Humphrey, unpublished observations). From these results it would be expected that anti-oestrogenic substances would be more effective in inhibiting oestrogen-dependent decidualization rather than those reactions which do not require oestrogen, and, conversely, that frank oestrogens would more effectively prevent deciduomata than implantation.

It was found that doses of Dms and oestradiol that would inhibit the deciduoma reaction in intact and ovariectomized mice did not completely prevent implantation (the present observations and see Stone \& Emmens, 1964a; Humphrey \& Martin, unpublished data). Conversely, doses of MRL 37 and MER 25 that inhibited oil-induced deciduomata and implantation in intact mice (both 
oestrogen-dependent reactions) did not completely inhibit deciduomata in ovariectomized mice. A more important observation is that these latter compounds inhibited oestradiol-induced implantation of delayed blastocysts, while DMs at two dose levels did not appear to do so, and seemed itself to induce implantation in some mice.

The inhibitory effects of MRL 37 and MER 25 on the oestrogen-dependent reactions in the present experiments suggest that they are acting as antioestrogens, while DMS appears to be oestrogenic.

It is interesting to compare the results obtained with MRL 37 and MER 25 with those obtained with the natural oestrogen, oestriol and the non-steroidal anti-oestrogen, U-11100A. These latter substances, termed impeded oestrogens, also interfere with the uterotrophic effects of oestradiol (Emmens \& Martin, $1964,1965)$, prevent oestradiol-induced implantation in ovariectomized mice (Humphrey, 1967a, c), and in these respects are acting as anti-oestrogens. Oestriol competes with oestradiol for uterine receptor binding sites (Brecher \& Wotiz, 1967) and it is surmised that the anti-oestrogenic effects of some impeded oestrogens are due to direct competition with other oestrogens at a common site (Emmens \& Martin, 1964).

However, MER 25, at least, is not anti-oestrogenic in vaginal tetrazolium tests and apparently does not displace oestrogen from its site of action in the vagina, but owes its anti-oestrogenic action to some other property (Emmens, 1965b). This worker has surveyed the oestrogenic, anti-oestrogenic and antifertility actions of a variety of anti-oestrogens and has concluded that the antifertility effects of DMs are probably due to its pro-oestrogenicity, but that MER 25 and MRL 37 may be acting by anti-oestrogenic pathways. The present findings would seem to support these conclusions.

\section{ACKNOWLEDGMENTS}

The author is grateful to Professor C. W. Emmens and Dr L. Martin for their advice and criticism. This work was supported by grants from the Population Council (U.S.A.).

\section{REFERENCES}

BrGGers, J. D. (1963) Discussion of 'Studies on interference with zygote development and implantation' by Nelson, Davidson and Wada. In: Delayed Implantation, p. 194. Ed. A. C. Enders. University of Chicago Press.

BRecher, P. I. \& Wotiz, H. H. (1967) Competition between oestradiol and oestriol for end organ receptor proteins. Steroids, $9(4), 431$.

BrounA, A. (1934) Etude des rapports entre les modifications pregravidiques de la muqueuse utérine et les hormones ovariennes. Archs Biol., Paris, 45, 571 .

Chang, M. C. (1959) Degeneration of ova in the rat and rabbit following oral administration of 1-( $p$-2diethylaminoethoxyphenyl)-1-phenyl-2-anisylethanol. Endocrinology, 65, 339.

Courrier, R. (1950) Interactions between oestrogens and progesterone. In: Vitamins and Hormones, Vol. VIII. Eds. R. S. Harris and K. V. Thimann. Academic Press, New York.

Davrs, B. K. (1963a) Termination of pregnancy in the rat with norethynodrel. Nature, Lond. 197, 308.

Davis, B. K. (1963b) Studies on the termination of pregnancy with norethynodrel. F. Endocr. 27, 99.

Emmens, C. W. (1965a) The oestrogenic and antifertility activities of diethylstilboestrol and dimethylstilboestrol in rodents. Acta endocr., Copenh. 49, 83.

Emmens, C. W. (1965b) The oestrogenic, anti-oestrogenic and antifertility activities of various compounds. J. Reprod. Fert. 9, 277. 
Emmens, C. W. \& Martin, L. (1964) Anti-oestrogens. In: Methods in Hormone Research, Vol. 2, chap. 2. Ed. R. I. Dorfman. Academic Press, New York.

Emmens, C. W. \& Martin, L. (1965) Biological activities of U-11100A. F. Reprod. Fert. 9, 269.

Fins, C. A. (1965) Oestrogens and the decidual cell reaction of implantation in mice. 7. Endocr. 32, 223.

FinN, C. A. (1966) Endocrine control of endometrial sensitivity during the induction of the decidual cell reaction in the mouse. 7 . Endocr. 36, 239.

Finn, C. A. \& Emmens, C. W. (1961) The effect of dimethylstilboestrol and oestradiol upon deciduoma formation in the rat. F. Reprod. Fert. 2, 528.

Humphrey, K. W. (1967a) The induction of implantation in the mouse after ovariectomy. Steroids, 10,591 .

Humphrey, K. W. (1967b) The development of viable embryos after ovum transfers to long-term ovariectomized mice. Steroids, 9, 53.

Humphrey, K. W. (1967c) The antifertility actions of some anti-oestrogens in the mouse. Proc. IIIrd Asia \& Oceania Conf. Endocr. Part II, Manila. Ed. A. D. Litohjua. In press.

Humphrey, K. W. \& Martin, L. (1968) The effects of oestrogens and anti-oestrogens on ovum transport in mice. 7. Reprod. Fert. 15, 191.

Jackson, H. (1966) Antifertility compounds in the male and female. Thomas, Springfield, Illinois.

Long, J. A. \& Evans, H. M. (1922) The oestrous cycle in the rat and its associated phenomena. Mem. Univ. Calif. 6, 1.

Malaren, A. \& Michie, D. (1956) Studies on the transfer of fertilized mouse eggs to uterine foster mothers. I. The factors affecting the implantation and survival of native and transferred eggs. F. exp. Biol. 33, 394.

Martin, L., Emmens, C. W. \& Cox, R. I. (1960) The effect of oestrogens and anti-oestrogens on early pregnancy in mice. F. Endocr. 20, 299.

RunNer, M. N. (1951) Differentiation of intrinsic and maternal factors governing intra-uterine survival of mammalian young. 7. exp. Zool. 116, 1.

Schlough, J. S. \& MeYeR, R. K. (1965a) Effect of anti-oestrogens on oestrogen induced ova implantation in the ovariectomized rat. Fert. Steril. 16, 106.

Schlough, J. S. \& MEYeR, R. K. (1965b) Suppression of the decidual response with oestrogen antagonists. Fert. Steril. 16, 596.

Segal, S. J. \& Nelson, W. O. (1958) An orally active compound with antifertility effects in rats. Proc. Soc. exp. Biol. Med. 98, 431.

SEgAL, S. J. \& TYLER, A. (1958) Structure-activity relationships concerning the inhibitory activity of synthetic oestrogens and some triphenylethanol derivatives on developing eggs of Arbacia punciulata. Biol. Bull. mar. biol. Lab., Woods Hole, 115, 304.

Shelessyax, M. G. \& KRAicer, P. F. (1961) A physiological method for inducing experimental decidualisation of the rat uterus: Standardisation and evaluation. J. Reprod. Fert. 2, 438.

Staplzs, R. E. (1966) Effect of clomiphene on blastocyst nidation in the rat. Endocrinology, 78, 82.

Stone, G. M. \& Emmens, C. W. (1964a) The effect of oestradiol and dimethylstilboestrol on early pregnancy and deciduoma formation in the mouse. 7 . Endocr. 29, 137.

Stone, G. M. \& Emmens, C. W. (1964b) The effect of oestrogens and anti-oestrogens on deciduoma formation in the rat. F. Endocr. 29, 147.

ZerLmaker, G. H. (1963) Experimental studies on the effects of ovariectomy and hypophysectomy on blastocyst implantation in the rat. Acta endocr., Copenh. 44, 355. 